\title{
EFFECT OF CARBADOX ON THE PASSAGE OF SULFAMETHAZINE THROUGH THE BLOOD-BRAIN BARRIER IN RAT*
}

\author{
A. B. SIDDIQUE, J. ŠIMƯNEK, E. HEGEROVÁ
}

Department of Pharmacology and Toxicology, University of Veterinary Science, 61242 Brno

Received February 2, 1979

\begin{abstract}
Siddique, A. B., J. Simůnek, E. Hegerová: Effect of Carbadox on the Passage of Sulfamethazine through the Blood-Brain Barrier in Rat. Acta vet. Brno, 48, 1979: $79-84$.
\end{abstract}

A relatively strong blood-brain barrier to sulfamethazine was observed in pregnant rats at two stages of gestation as well as in their non-pregnant counterparts. Passage of sulfamethazine from blood to brain was found to be slow and difficult. Carbadox, a non-antibiotic synthetic growth promotant, did not appear to influence this blood-brain barrier to sulfamethazine in any significant way. Sulfamethazine concentrations in the blood and brains of rats which were fed the carbadox-medicated diet did not differ significantly from those in the blood and brains of rats which did not receive it.

Sulfamethazine, carbadox, passage, blood-brain barrier, rat.

The blood-brain barrier has been defined as a mechanism, unique to central nervous system (CNS), for exchange of substances between plasma and intercellular fluid. This barrier is generally believed to consist of the selectively permeable layer of CNS capillary endothelium (Timiras et al. 1968; Crone and Thompson 1970). However, a number of tissue layers other than the capillary endothelium have been proposed as the site of the blood-brain barrier (Wilson 1968). The exchange processes across the blood-brain barrier have been discussed by Woodbury (1965).

The rate of growth of mammalian brain is most rapid before birth; but, in species like rats, rabbits and mice which are born in an immature state, myelination of the brain begins a week or two after birth (Widdowson 1968).

Entry of many drugs into the fluid environment of CNS cells is significantly restricted by their failure to penetrate the blood-brain barrier. Passage of substances through the blood-brain barrier depends on their physicochemical properties. According to Ariëns et al. (1964), the blood-brain barrier appears to behave as a lipid membrane. Therefore, a lipid-insoluble substance will pass the barrier with difficulty, but a lipid-soluble drug will reach the same free concentration on both sides of the barrier. However, the blood-brain barrier represents a unique example of unequal distribution of drugs (Brodie and Hogben 1957). Even if injected intravenously, many drugs fail to penetrate into the CNS (Goth 1970). The blood-brain relationship for each and every substance is different (Dobbing 1961).

Sulfonamides are believed to penetrate the blood-brain barrier in variable degrees (Golds worthy et al. 1954). Physico-chemical properties of sulfonamides especially of lipid-solubility, protein binding, molecular configuration and acidic properties have been reported to bear an important relationship to the permeability of these compounds through the blood-brain barrier (Goth 1970; Oldendorf 1974). Sulfamethazine, a lipid-soluble, and poorly ionized drug of low molecular weight has been found to penetrate the blood-brain barrier differently in various species of animals and at different stages of brain development (Siddique and Šimůnek 1977).

Carbadox [methyl 3-(2-quinoxalinylmethylene) Carbazate $\mathrm{N}^{1}, \mathrm{~N}^{4}$ dioxide], a non-antibiotic

** Part of a research project under an UNESCO Fellowship Programme, organized by the Microbiology Institute of the Czechoslovak Academy of Sciences, Prague. 
synthetic growth promotant for animals, has been extensively used in many countries of the world. It is also widely used for the prevention and treatment of some of the animal diseases. Carbadox is effective against a wide variety of both gram-positive and gram-negative bacteria. The spectrum activity of carbadox along with its efficacy in systemic use for the control of artificially induced infections in laboratory animals have been described by English and Lynch (1971).

The present paper reports of the effect of carbadox on the passage of sulfamethazine through the blood-brain barrier of rat. This study was undertaken primarily to find out a probable basis on which to consider the effect on the sulfamethazine therapy by the carbadox in premedicated farm animals.

\section{Materials and Methods}

Carbadox was supplied by the Czechoslovak National Chemical Industries, Lachema, Brno. Sulfamethazine was a product of Czechoslovak National Enterprise, Spofa. Wistar rats were obtained from the experimental animal farm of the Slovak Academy of Sciences, Dobrá Voda.

Pregnant rats were divided into two groups. One group was fed the Larsen diet (standard feed mixture for rat) mixed with carbadox powder at the rate of $50 \mathrm{mg} / \mathrm{kg}$ Larsen. The second group of rats was fed only the Larsen diet. On the 10th day and on the 20th day of pregnancy each of these two groups was again divided into 3 sub-groups (each sub-group containing at least 5 pregnant rats) and were injected $\mathrm{i} . \mathrm{m}$. a freshly prepared $10 \%$ sodium-sulfamethazine solution at the dose of $0.3 \mathrm{~g} / \mathrm{kg}$ body mass. The rats were decapitated at intervals of 60,120 and 240 minutes from drug administration, one sub-group being decapitated at each of the three time periods. Samples of blood and brain from each animal were collected at each time period. Simultaneous identical experiments (as control against pregnant rats) with adult non-pregnant female rats were carried out on each occasion following identical procedures.

Sulfamethazine concentration of each sample was determined according to the method of Bratton and Marshall (1939), modified by Wagner (1950). The mean, S. E. and the level of

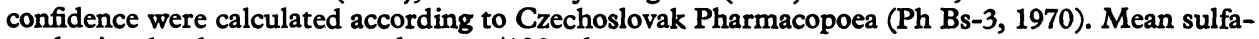
methazine levels are expressed as $\mathrm{mg} / 100 \mathrm{ml}$.

\section{Results}

Rats which received carbadox medicated diet:

Sulfamethazine level in the blood of pregnant rats, on the day 10 of gestation, was found to be $17.27 \pm 0.35 \mathrm{mg} / 100 \mathrm{ml}$ after 60 minutes of drug administration. The corresponding brain level was $5.71 \pm 0.45 \mathrm{mg} / 100 \mathrm{ml}$ and this amounted to about $33 \%$ of the blood level. Both blood and brain levels rose to peak after

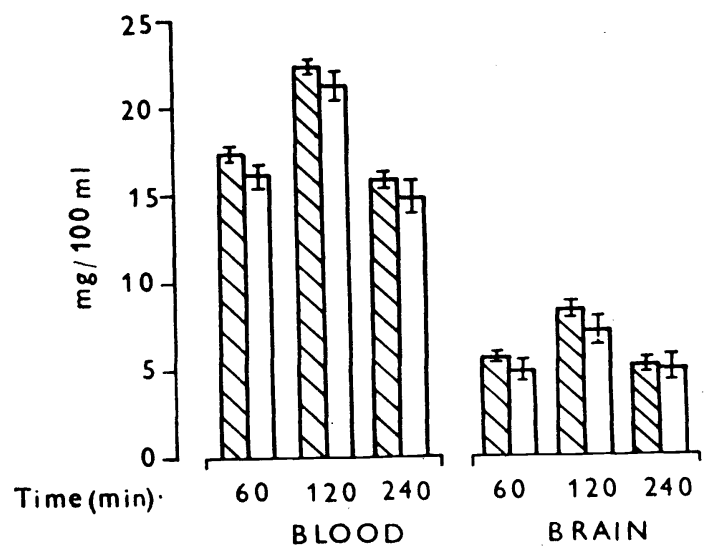

00 Pregnant Graph 1.
120 minutes of drug administration. The peak blood level was $22.23 \pm 0.30 \mathrm{mg} / 100 \mathrm{ml}$. The peak brain level was $8.30 \pm$ $\pm 0.35 \mathrm{mg} / 100 \mathrm{ml}$ which represented about $37 \%$ of the peak blood level. After 240 minutes of drug administration, both blood and brain levels were found to have dropped. The blood level dropped to $15.55 \pm$ $\pm 0.35 \mathrm{mg} / 100 \mathrm{ml}$ and the brain level dropped to $5.11 \pm 0.35 \mathrm{mg} /$ $/ 100 \mathrm{ml}$ representing about $32 \%$ of blood level. Similar data were found in case of non-pregnant animals. Results are illustrated in Graph 1. 
Sulfamethazine levels in blood and brains of pregnant rats, on the 20th day of gestation, were $23.44 \pm 0.45 \mathrm{mg} / 100 \mathrm{ml}$ and $7.35 \pm 0.35 \mathrm{mg} / 100 \mathrm{ml}$ respectively after 60 minutes of drug administration. The brain level mounted to about $31 \%$ of the blood level. Both levels reached their peak after 120 minutes. The peak blood level was $31.51 \pm 0.55 \mathrm{mg} / 100 \mathrm{ml}$ and the peak brain level was $11.11 \pm$ $\pm 0.45 \mathrm{mg} / 100 \mathrm{ml}$ which amounted to about $35 \%$ of the blood level. Both blood and brain level dropped after 240 minutes. The blood level dropped to $25.20 \pm$ $\pm 0.55 \mathrm{mg} / 100 \mathrm{ml}$ while the brain level dropped to $8.30 \pm 0.55 \mathrm{mg} / 100 \mathrm{ml}$ amounting to about $32 \%$ of the blood level. Data of non-pregnant female rats were found to be approximately similar. Blood and brain levels of both pregnant and non-pregnant animals are shown in Graph 2.

Rats which did not receive carbadox medicated diet:

In pregnant rats on the 10th day of pregnancy, the blood level was $17.24 \pm 0.50 \mathrm{mg} / 100 \mathrm{ml}$ after 60 minutes. The corresponding brain level at that time period was $5.15 \pm 0.45 \mathrm{mg} / 100 \mathrm{ml}$ amounting to about $30 \%$ of the blood level. As in previous cases, both blood and brain levels rose to their peak after 120 minutes of drug administration. The peak brain level of $8.25 \pm 0.55 \mathrm{mg} /$ $/ 100 \mathrm{ml}$ was about $36 \%$ of the corresponding peak blood level of $22.75 \pm 0.55 \mathrm{mg} / 100 \mathrm{ml}$. After 240 minutes, the blood level dropped to $15.80 \pm 0.55 \mathrm{mg} / 100 \mathrm{ml}$ while the brain level dropped to $5.15 \pm 0.55 \mathrm{mg} / 100 \mathrm{ml}$ and this amounted to about $32 \%$ of the corresponding blood level. Similar results were found in non-pregnant rats. Results are shown in Graph 3.

Blood and brain levels of pregnant rats, on the day 20 of gestation, were $23.78 \pm 1.06 \mathrm{mg} /$ $/ 100 \mathrm{ml}$ and $8.05 \pm 0.78 \mathrm{mg} /$ $/ 100 \mathrm{ml}$ respectively after $60 \mathrm{mi}$ nutes of drug administration. The brain level was about $33 \%$ of the blood level. After 120

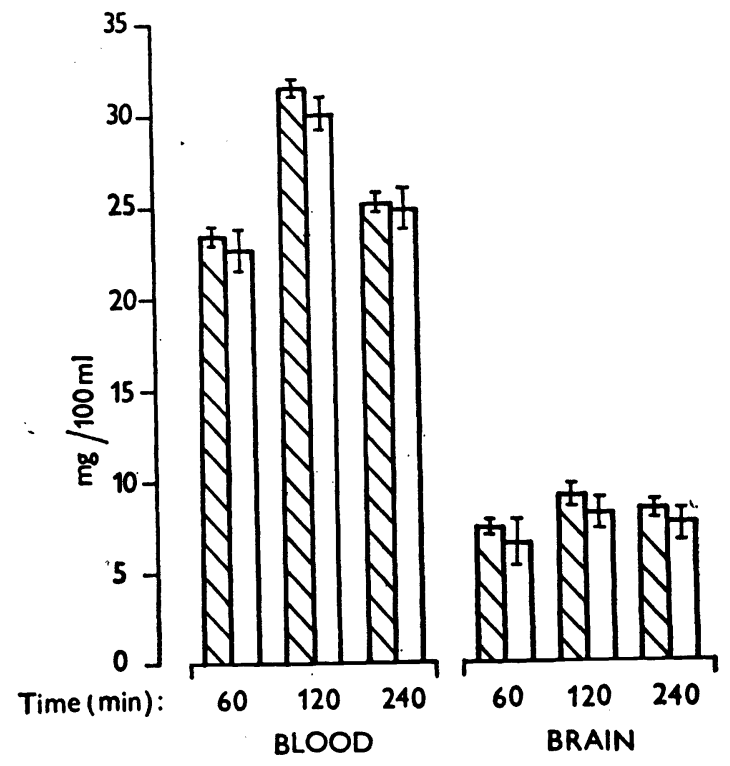

$\square$ Pregnant $\square$ Nonpregnant

Graph 2.

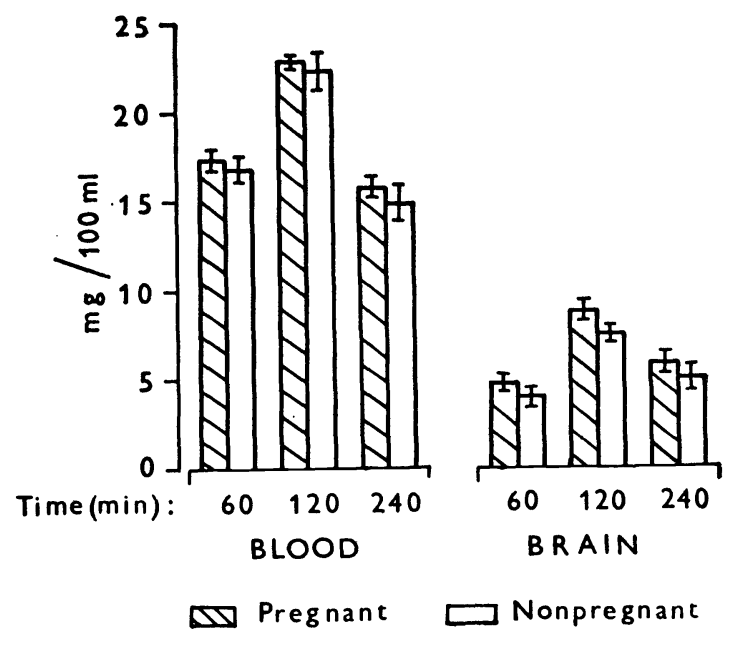

Graph 3. 
minutes, the peak brain level of $10.83 \pm 0.57 \mathrm{mg} / 100 \mathrm{ml}$ amounted to about $35 \%$ of the peak blood level of $30.72 \pm 0.56 \mathrm{mg} / 100 \mathrm{ml}$. After 240 minutes, the blood level was found to have dropped to $25.68 \pm 0.68 \mathrm{mg} / 100 \mathrm{ml}$. The brain level dropped to $8.77 \pm 0.97 \mathrm{mg} / 100 \mathrm{ml}$ which was about $34 \%$ of the brain level at that time period. Similar findings were observed in non-pregnant females. Results are illustrated in Graph 4.

Blood levels of pregnant animals were, in general, little higher than those of their non-pregnant counterparts. Blood levels of 20 days pregnant rats were higher

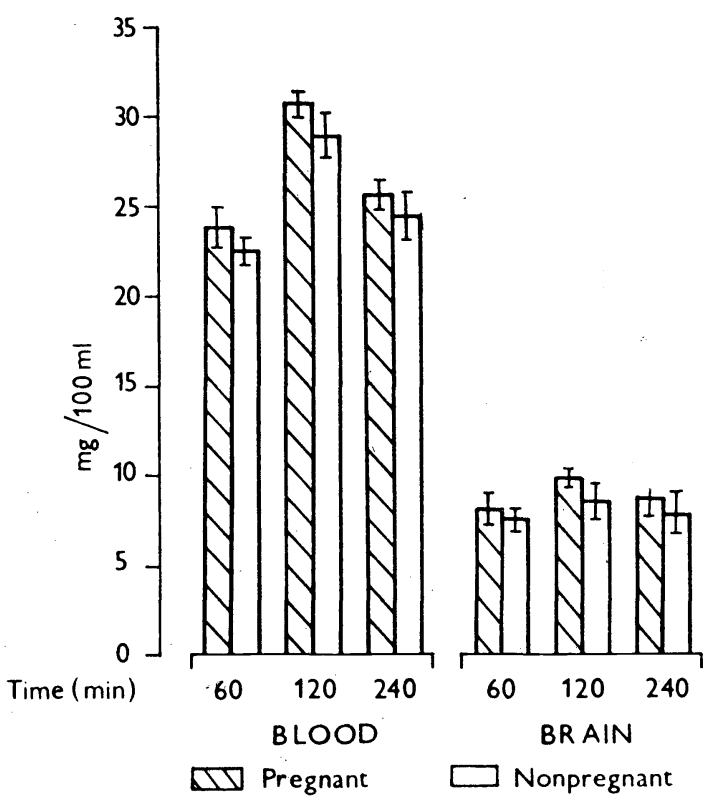

Graph 4. than those of 10 days pregnant ones.

\section{Discussion}

The present investigation was carried out within the scope of the study of the effect of carbadox on the placental transfer of sulfamethazine at two stages of gestation in rat. Our present data have demonstrated the existence of significant blood-brain barrier to sulfamethazine in adult rats, both pregnant and non-pregnant. Sulfamethazine concentrations in the brains were always found to be significantly lower than those in the blood. Similar findings were observed in both groups of rats irrespective of the fact that one group of rats was fed carbadox-medicated diet while the other group did not receive this diet. Sulfamethazine levels in the blood and brains of rats which received carbadox-medicated food did not differ significantly from those in the blood and brains of rats which did not receive carbadox in their food. In all cases, sulfamethazine appeared to pass from blood to brain with difficulty. The passage was found to be slow and restricted indicating the presence of a relatively strong blood-brain barrier to sulfamethazine in adult rats. Carbadox did not appear to influence this barrier to sulfamethazine in rat in any significant way.

It is known that permeation of membranes by drugs is facilitated by lipid solubility of the nonionized molecules (Scholtan 1961). Yet various sulfonamides show a relatively wide dispersion within this general trend which suggest that the described relationship is influenced by a number of factors not sufficiently known (Struller 1968).

The present findings as regards the passage of sulfamethazine from blood to brain are in conformity with our previous findings (Siddique and Šimůnek 1977) as well as with other reports. Distribution of sulfonamides from blood to brain is the lowest in comparison to other tissues of the body (Schipper 1964; Staib 1967). According to Ariëns et al. (1964), sulfamethazine is one of those 
sulfonamides which do not easily penetrate the blood-brain barrier. Goldsworthy et al. (1954) found no correlation between the lipid solubility of sulfonamides and their permeability through the blood-brain barrier.

The disparity between the rapid rate of blood flow to the central nervous system, and the slow entry of many substances, provides the most convincing evidence of unusual permeability properties in these tissues (Sherman 1970).

Our present findings indicate that carbadox has practically no effect on the therapeutic use of sulfamethazine in animals.

\section{Vliv carbadoxu na prostup sulfadimidinu hematoencefalickou bariérou}

$\mathrm{V}$ pokusech byla zjištěna poměrně malá propustnost hematoencefalické bariéry pro sulfadimidin u krys ve dvou stadiích březosti i u krys kontrolních - nebřezích. Ukázalo se, že prostup sulfadimidinu z krve do mozku je pomalý.

Carbadox - neantibiotický stimulátor růstu, nevykázal nijaký významný vliv na funkci hematoencefalické bariéry či průniku sulfadimidinu. Koncentrace sulfadimidinu $\mathrm{v}$ krvi a mozku krys, kterým bylo podáváno krmivo medikované carbadoxem, se nelišily významně od koncentrací v krvi a mozku krys, kterým carbadox podáván nebyl.

\section{Влияние карбадокса на пропускание сульфадимидина гемато- -энцефалическим барьером}

В ходе опытов была выявлена довольно небольшая проницаемость гематоэнцефалического барьера для сульфадимидина крыс в двух стадиях беременности и контрольных, не беременных крыс. Было установлено, что пропускание сульфадимидина из крови в мозг является медленным.

Карбадокс - неантибиотический стимулятор роста, не оказывал никакого существенного влияния на функцию гемато-энцефалического барьера или проникновение сульфадимидина. Концентрация сульфадимидина в крови и мозгу крыс, получавших корм с карбадоксом, существенно не отличалась от концентрации в крови и мозгу крыс, не принимавших карбадокса.

\section{References}

ARIËNS, E. J. - Von OS, G. A. J. - SIMONIS, A. M. - Von ROSSUM, J. M.: In molecular Pharmacology (ARIËNS, E. J., editor). Vol. 1, Acad. Press, New York and London 1964: p. $7-9$.

BRATTON, A. A. - MARSHALL, E. K.: A new coupling component for sulfanilamide determination. J. Biol. Chem., 128, 1939: 537-550.

BRODIE, B. B. - HOGBEN, C. A. M.: Some physicochemical factors in drug action. J. Pharm. Pharmacol., 9, 1957: 345.

CRONE, C. - THOMPSON, A. M.: In Capillary Permeability (CRONE, C. - LASSEN, N., editors). Acad. Press, New York, 1970: p. 447.

DOBBING, J.: The blood-brain barrier. Physiol. Rev., 41, 1961: 188.

ENGLISH, A. R. - LYNCH, J. E.: Carbadox, a new synthetic agent effective against gramnegative bacteria. Proc. Carbadox Symp., Kansas City (PFIZER edit.), 1971: p. 16-26.

GOLDSWORTHY, P. D. - AIRD, R. B. - BECKER, E. A.: The blood-brain barrier - the effect of acidic dissociation constant on the permeation of certain sulfonamides into the brain. J. Cell. Comp. Physiol., 44, 1954: 519-526.

GOTH, A.: Medical pharmacology, 5th ed., The C. V. Mosby Company, Saint Louis, 1970: p. $507-523$.

OLDENDORF, W. H.: Lipid solubility and drug penetration of the blood-brain barrier. Proc. Soc. exp. Biol. Med., 147, 1974: 813-816.

SCHIPPER, I. A.: Rates and routes of sulfonamide excretion in the cow. Blood levels following single intravenous and oral administrations. Brit. Vet. J., 120, 1964: 273-278. 
SCHOLTAN, W. Die Bindung der Langzeit-Sulfonamide an die Eiweisskörper des Serums. Arzneim-Forsch., 11, 1961: 707-720.

SHERMAN, G. P.: A possible determinant of drug action- the blood-brain barrier. Am. J. Pharm., 142, 1970: $127-133$.

SIDDIQUE, A. B. - ŞIMUீNEK, J.: Blood-brain barrier to sulfamethazine in rat, sheep and sheep fetuses. Acta vet. Brno, 46, 1977: 101-109.

STAIB, H. A.: EKG-Veränderungen bei der Ratte nach Chlorpromazin im Verlauf der postnatalen Entwicklung. Arch. int. Pharmacodyn., 166, 1967: 11-19.

STRULLER, Th.: Long-Acting and Short-Acting Sulfonamides. Recent developments. Antibiot. Chemotherap (Basel)., 14, 1968: 179-215.

TIMIRAS. P. S. - VERNADAKIS, A. - SHERWOOD, N. M.: Development of plasticity of the nervous system: In Biology of Gestation (ASSALI, N. S., editor). Vol. 2., Acad. Press, New York, 1968: p. 279-280.

WAGNER, J.: Mikrostanovení sulfonamidů pro klinické účely. Cas. Lék. čes., 89, 1950: 262-264.

WIDDOWSON, E. M.: Growth and composition of the fetus and newborn: In Biology of Gestation (ASSALI, N. S., editor). Vol. 2., Acad. Press, New York 1968: p. 40.

WILSON, J. G.: Environmental effects on development-teratology: In Pathophysiology of Gestation (ASSALI, N. S., editor). Acad. Press, New York, 1968: p. 269-320.

WOODBURY, D. M.: In Physiology and Biophysics (RUCH, T. C. - PATTON, H. D., editors)., Saunders, Philadelphia, 1965: p. 942-950. 